\title{
Molecular Identification and Ultrastructural and Phylogenetic Studies of Cyanobacteria from Association with the White Sea Hydroid Dynamena pumila (L., 1758)
}

\author{
O. A. Koksharova, ${ }^{1,2}$ T. R. Kravzova, ${ }^{3}$ I. V. Lazebnaya, ${ }^{4}$ O. A. Gorelova, ${ }^{3}$ \\ O. I. Baulina, ${ }^{3}$ O. E. Lazebny, ${ }^{5}$ T. A. Fedorenko, ${ }^{3}$ and E. S. Lobakova ${ }^{3}$ \\ ${ }^{1}$ Lomonosov Moscow State University, Belozersky Institute of Physico-Chemical Biology, Leninskie Gory 1-40, Moscow 119992, Russia \\ ${ }^{2}$ Institute of Molecular Genetics, Russian Academy of Sciences, Moscow 123182, Russia \\ ${ }^{3}$ Lomonosov Moscow State University, Faculty of Biology, Leninskie Gory 1-12, Moscow 119991, Russia \\ ${ }^{4}$ N.I.Vavilov Institute of General Genetics, Russian Academy of Science, Gubkin Street 3, Moscow 119333, Russia \\ ${ }^{5}$ N.K.Kol'tsov Institute of Developmental Biology, Russian Academy of Science, Vavilova Street 26, Moscow 119334, Russia
}

Correspondence should be addressed to O. A. Koksharova; oa-koksharova@rambler.ru

Received 28 February 2013; Accepted 22 April 2013

Academic Editor: Vassily Lyubetsky

Copyright (C) 2013 O. A. Koksharova et al. This is an open access article distributed under the Creative Commons Attribution License, which permits unrestricted use, distribution, and reproduction in any medium, provided the original work is properly cited.

Three new cyanobacterial strains, that have been previously purified from the hydroid Dynamena pumila (L., 1758), isolated from the White Sea, were studied using scanning and transmission electron microscopy methods and were characterized by using almost complete sequence of the 16S rRNA gene, internal transcribed spacer 16S-23S rRNA, and part of the gene for 23S rRNA. The full nucleotide sequences of the rRNA gene clusters were deposited to GenBank (HM064496.1, GU265558.1, JQ259187.1). Comparison of rRNA gene cluster sequences of Synechococcus cyanobacterium 1Dp66E-1, Oscillatoriales cyanobacterium 2Dp86E, and Nostoc sp. 10Dp66E with all sequences present at the GenBank shows that these cyanobacterial strains do not have $100 \%$ identity with any organisms investigated previously. Furthermore, for the first time heterotrophic bacterium, associated with Nostoc sp. 10Dp66E, was identified as a member of the new phylum Gemmatimonadetes, genus of Gemmatimonas (GenBank accession number is JX437625.1). Phylogenetic analysis showed that cyanobacterium Synechococcus sp. 1Dp66E-1 forms the unique branch and belongs to a cluster of Synechococcus, including freshwater and sea strains. Oscillatoriales cyanobacterium 2Dp86E belongs to a cluster of Leptolyngbya strains. Isolate Nostoc sp. 10Dp66E forms unique branch and belongs to a cluster of the genus Nostoc, with the closest relative of Nostoc commune isolates.

\section{Introduction}

Cyanobacterial symbioses and associations with eukaryotes are widely distributed in aquatic and terrestrial environments. Various cyanobacterial strains form associations with sponges, hydroids, corals, dinoflagellates, radiolarians, and tintinnids [1-8]. Mostly, the studies of cyanobacterial associations are limited to subtropical and tropical marine water systems. Symbioses and associations between cyanobacteria and marine animals of high latitudes are poorly studied. Recently we isolated the several cyanobacteria from the associations with White Sea hydroid Dynamena pumila (L., 1758) [7]. Purification of the symbiotic cyanobacteria from the associations with animals is rarely successful. Four cyanobacteria were isolated and purified into culture from native samples of hydroid $D$. pumila and were identified based on morphological characteristics as representatives of the I, II, and IV subsections of phylum BX Cyanobacteria [7].

The goal of this study was the identification of the new cyanobacteria from association with the hydroid Dynamena pumila and their characterization on the basis of ultrastructural and molecular features. 

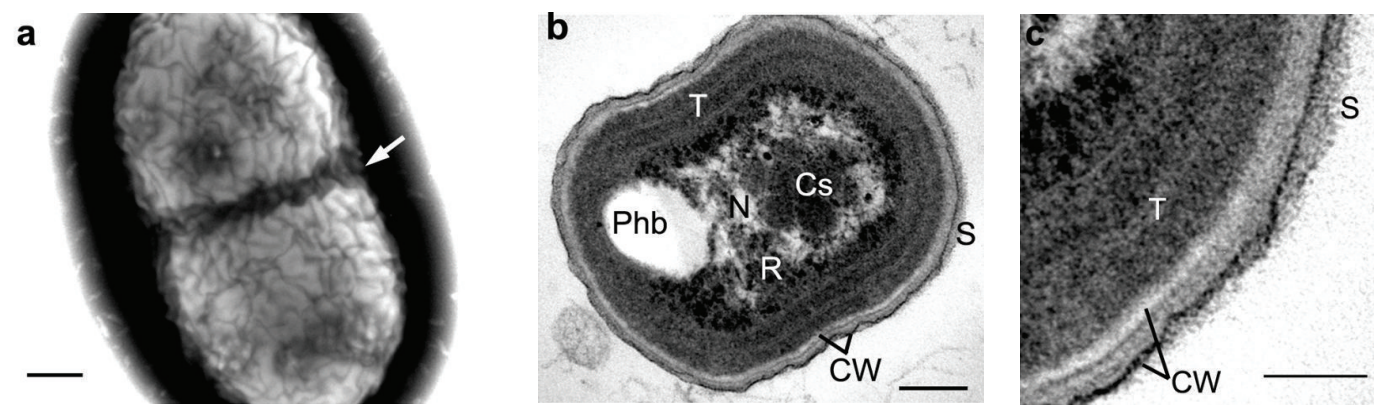

Figure 1: Ultrastructure of cyanobacterium 1Dp66E-1: a: TEM negative staining image; b: TEM ultrathin section; c: enlarged detail of Figure 1(b). Cs: carboxysome; CW: cell wall; N: nucleoid; Phb: poly- $\beta$-hydroxybutyrate; R: ribosomes; S: S-layer; T: thylakoid. Arrows indicate site of constriction. Scale bars: $0.2 \mu \mathrm{m}(\mathbf{a}, \mathbf{b})$ and $0.1 \mu \mathrm{m}(\mathbf{c})$.
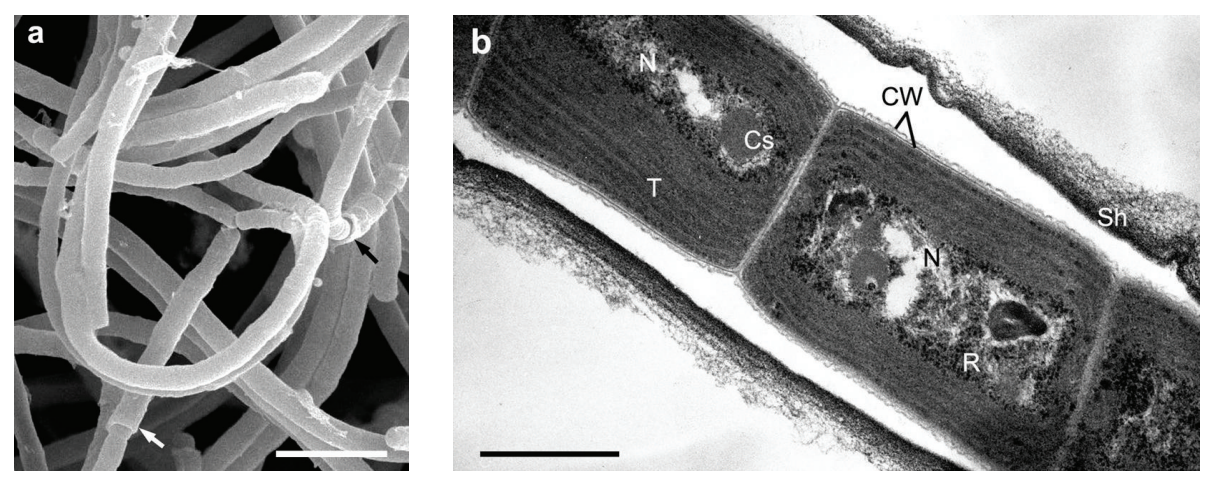

FIGURE 2: Ultrastructure of cyanobacterium 2Dp86E: a: SEM image; b: TEM ultrathin section. Cs: carboxysome; CW: cell wall; N: nucleoid; R: ribosomes; T: thylakoids; Sh: sheath. Arrows indicate sleeve-like thickening of sheath. Scale bars: $5 \mu \mathrm{m}(\mathbf{a})$ and $0.5 \mu \mathrm{m}(\mathbf{b})$.

\section{Materials and Methods}

2.1. Organisms and Growth Conditions. Cyanobacterial isolates 1Dp66E-1, 2Dp86E, and 10Dp66E have been previously purified from the samples of the hydroid Dynamena pumila (L., 1758) collected in June and August of 2006 in the Rugozero Bay of the Kandalaksha Gulf of the White Sea $\left(66^{\circ} 34^{\prime} \mathrm{N}, 33^{\circ} 08^{\prime} \mathrm{E}\right)$ [7]. Cyanobacterial isolates 1Dp66E-1, $2 \mathrm{Dp} 86 \mathrm{E}$, and $10 \mathrm{Dp} 66 \mathrm{E}$ have been grown on solid (1.5\% agar) and liquid medium BG-11 [9] at $25^{\circ} \mathrm{C}$ and an illumination of $50 \mu \mathrm{mol}$ photons $\mathrm{m}^{-2} \mathrm{~s}^{-1}$.

2.2. Light Microscopy. The isolated cyanobacteria have been studied under Leitz Laborlux D microscope (Ernst Leitz Wetzlar GmbH, Germany).

2.3. Transmission Electron Microscopy (TEM). For negative staining, drop of cyanobacteria suspension was placed onto grids and treated with $1 \%(\mathrm{w} / \mathrm{v})$ sodium phosphotungstate solution and dried. For the preparation of ultrathin sections, cyanobacteria were fixed in $2 \%(\mathrm{w} / \mathrm{v})$ glutaraldehyde in $0.1 \mathrm{M}$ sodium cacodylate buffer $(\mathrm{pH} 7,2)$ for $0.5 \mathrm{~h}$ and then postfixed in $1 \%(\mathrm{w} / \mathrm{v})$ osmium tetroxide in the same buffer for $4 \mathrm{~h}$, dehydrated by incubation in dilutions of ethanol, including absolute ethanol saturated with uranyl acetate, and embedded in araldite. Thin sections were prepared on an LKB8800 (Sweden) ultratome and stained with lead citrate [10].
Ultrathin sections were examined with transmission electron microscopes JEM-100B and JEM-1011 (JEOL, Japan).

2.4. Scanning Electron Microscopy (SEM). Cyanobacterial samples were fixed as described above and dehydrated through an ethanol series, with an overnight exposure in absolute acetone followed by critical-point drying in a Dryer HCP-2 (Hitachi, Japan), coated with Au-Pd alloy in an IB-3 Ion Coater (Eiko, Japan), and examined with a JSM-6380LA scanning electron microscope (JEOL, Japan).

2.5. DNA Isolation and PCR Amplification. The DNA samples from cyanobacterial isolates 1Dp66E-1, 2Dp86E, and $10 \mathrm{Dp} 66 \mathrm{E}$ were isolated according to the method of Koksharova [11]. The synthetic oligonucleotides (Table 1, "Synthol," Moscow, Russia) have been used as primers in the PCR reactions [12] in case of cyanobacterial isolates 1Dp66E-1, 2Dp86E, and 10Dp66E.

PCR was carried out on a Tercik DNA amplifier (DNA Technology, Russia) by using DreamTaq PCR Master Mix (Fermentas, EU), under the following conditions: 1 cycle at $94^{\circ} \mathrm{C}$ for $10 \mathrm{~min}, 25 \mathrm{cycles}$ at $94^{\circ} \mathrm{C}$ for $45 \mathrm{sec}, 54^{\circ} \mathrm{C}$ for $45 \mathrm{sec}$, $68^{\circ} \mathrm{C}$ for $2 \mathrm{~min}, 1 \mathrm{cycle}$ at $68^{\circ} \mathrm{C}$ for $7 \mathrm{~min}$, and a final soak step at $4^{\circ} \mathrm{C}$. PCR products were resolved in $1.5 \%$ agarose gel containing ethidium bromide at 5 microgram $\mathrm{mL}^{-1}$. All experiments were repeated at least three times. 
TAble 1: Primers.

\begin{tabular}{|c|c|c|}
\hline $\begin{array}{l}\text { Strain and a name of } \\
\text { the primer }\end{array}$ & $5^{\prime}-3^{\prime}$ nucleotide sequence of the primer & $\begin{array}{l}\text { Reference and a reaction } \\
\text { where a primer was used }\end{array}$ \\
\hline 10Dp66E, 16S27F & AGAGTTTGATCCTGGCTCAG & PCR \\
\hline $\begin{array}{l}\text { 1Dp66E-1, 2Dp86E } \\
\text { 16S378F }\end{array}$ & GGGGAATTTTCCGCAATGGG & [23], PCR \\
\hline $\begin{array}{l}\text { 1Dp66E-1, 2Dp86E, } \\
\text { 10Dp66E } \\
23 S 30 R\end{array}$ & CTTCGCCTCTGTGTGCCTAGGT & [24], PCR \\
\hline $\begin{array}{l}\text { 1Dp66E-1, 2Dp86E } \\
\text { 16S534F }\end{array}$ & GCCCACAGCTCAACTGTGG & This work, PCR \\
\hline $\begin{array}{l}\text { 1Dp66E-1, 2Dp86E } \\
\text { 23S1665R }\end{array}$ & CGCTCTAACCACCTGAGC & This work, PCR \\
\hline $\begin{array}{l}\text { 2Dp86E } \\
\text { CYA781 Rfil }\end{array}$ & GACTACTGGGGTATCTAATCCCATT & This work, sequencing \\
\hline $\begin{array}{l}\text { 1Dp66E-1 } \\
\text { CYA781Rnonfil }\end{array}$ & GACTACAGGGGTATCTAATCCCTTT & This work, sequencing \\
\hline $\begin{array}{l}\text { 2Dp86E } \\
\text { FIL6F }\end{array}$ & CATGTCGCGAATCTTTCAG & This work, sequencing \\
\hline $\begin{array}{l}\text { 2Dp86E } \\
\text { FIL7F }\end{array}$ & CGTCCTACAATGCTACAGAC & This work, sequencing \\
\hline $\begin{array}{l}\text { 2Dp86E } \\
\text { FIL } 8 F\end{array}$ & CGAGTGGTCACTCTAGG & This work, sequencing \\
\hline $\begin{array}{l}\text { 2Dp86E } \\
\text { FIL9F5 }\end{array}$ & CGACTGACTGGACTAATGG & This work, sequencing \\
\hline $\begin{array}{l}\text { 2Dp86E } \\
\text { FIL10R }\end{array}$ & AACCGCTGACATCCTGCT & This work, sequencing \\
\hline $\begin{array}{l}\text { 2Dp86E } \\
\text { FIL11R }\end{array}$ & GTGAGCCCGTTGTAGCTT & This work, sequencing \\
\hline $\begin{array}{l}\text { 1Dp66E-1 } \\
\text { UNI } 3 F\end{array}$ & ATGGACGAAAGCCAGGGGAGC & This work, sequencing \\
\hline $\begin{array}{l}\text { 1Dp66E-1 } \\
\text { UNI } 4 R\end{array}$ & GACCTGCGATTACTAGCGATG & This work, sequencing \\
\hline $\begin{array}{l}\text { 1Dp66E-1 } \\
\text { UNI 5F }\end{array}$ & GGCGTTCAACGTGTCCGATCC & This work, sequencing \\
\hline $\begin{array}{l}\text { 1Dp66E-1 } \\
\text { UNI 6R }\end{array}$ & GAGTCCTCAGCTGAACATGTCC & This work, sequencing \\
\hline $\begin{array}{l}\text { 1Dp66E-1 } \\
\text { UNI 7F }\end{array}$ & GTGAGCCCGTTGTAGCTT & This work, sequencing \\
\hline $\begin{array}{l}\text { 1Dp66E-1 } \\
\text { UNI 1F }\end{array}$ & CTCGGTGTCGTAGCTAACGC & This work, sequencing \\
\hline $\begin{array}{l}\text { 1Dp66E-1 } \\
\text { UNI 1R }\end{array}$ & CATCCTGCTTGCAAAGCAG & This work, sequencing \\
\hline $\begin{array}{l}\text { 1Dp66E-1 } \\
\text { UNI } 8 R\end{array}$ & GAGGTTTACAGCCCAGAG & This work, sequencing \\
\hline $\begin{array}{l}\text { 1Dp66E-1 } \\
\text { UNI 9R }\end{array}$ & GCATCGAATTAAACCAC & This work, sequencing \\
\hline $\begin{array}{l}\text { 1Dp66E-1 } \\
\text { UNI 10F }\end{array}$ & GACAGGTGGTGCATGGC & This work, sequencing \\
\hline $\begin{array}{l}\text { 10Dp66E } \\
10 D p F\end{array}$ & GCTGACCTGCAATTACTAGC & This work, sequencing \\
\hline $\begin{array}{l}\text { 10Dp66E } \\
\text { 10DpR }\end{array}$ & GCGCTTTCGCCACCGGTGTTC & This work, sequencing \\
\hline $\begin{array}{l}\text { 1Dp66E-1, 2Dp86E } \\
\text { 16S15-12-08F }\end{array}$ & GCCCACAGCTCAACTGTGG & This work, sequencing \\
\hline
\end{tabular}


TABLE 1: Continued.

\begin{tabular}{lcc}
\hline $\begin{array}{l}\text { Strain and a name of } \\
\text { the primer }\end{array}$ & $5^{\prime}-3^{\prime}$ nucleotide sequence of the primer & $\begin{array}{l}\text { Reference and a reaction } \\
\text { where a primer was used }\end{array}$ \\
\hline $\begin{array}{l}\text { 1Dp66E-1, 2Dp86E } \\
\text { 23S15-1208R }\end{array}$ & GGCCATCCTGGACTCGAAC & This work, sequencing \\
$\begin{array}{l}\text { 1Dp66E-1, 2Dp86E } \\
\text { 23S16-1208R }\end{array}$ & CGCTCTAACCACCTGAGC \\
$\begin{array}{l}\text { 1Dp66E-1, 2Dp86E } \\
\text { 23S31R }\end{array}$ & CTCAACCATAGTCTAGAAAC & This work, sequencing \\
1Dp66E-1, 2Dp86E & GTCCTGAACGACCTAGAG & This work, sequencing \\
23S32R & & This work, sequencing \\
\hline
\end{tabular}
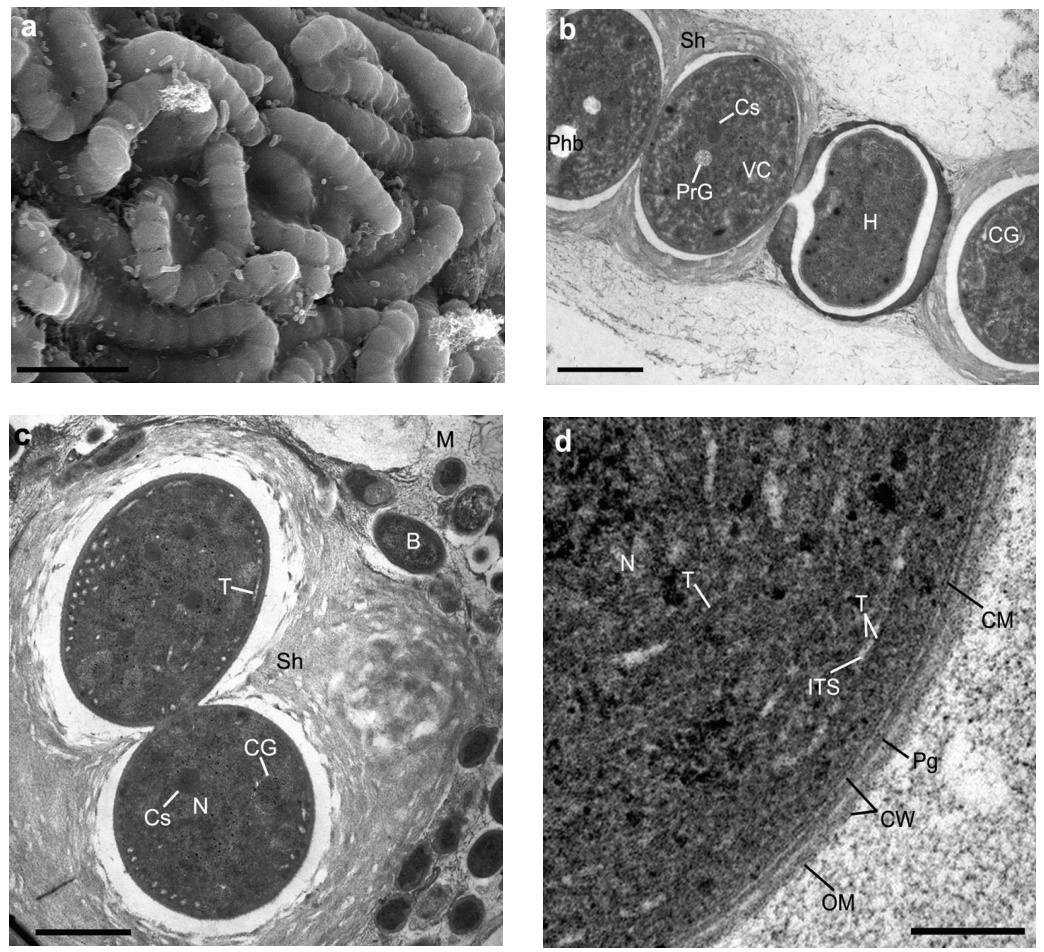

FIGURE 3: Ultrastructure of cyanobacterium 10Dp66E: a: SEM image; b: TEM ultrathin section of vegetative trichome; c: TEM ultrathin section of cell cluster; $\mathbf{d}$ : TEM ultrathin section of the cell part in the cell wall and thylakoids areas. B: bacteria; CG: cyanophycin granule; CM: cytoplasmic membrane; Cs: carboxysome; CW: cell wall; H: heterocyst; ITS: intrathylakoid space; M: intercellular matrix; N: nucleoid; OM: outer membrane; Pg: peptidoglycan; Phb: poly- $\beta$-hydroxybutyrate; PrG: protein granules; Sh: sheath; T: thylakoids; VC: vegetative cell. Scale bars: $10 \mu \mathrm{m}(\mathbf{a}), 1 \mu \mathrm{m}(\mathbf{b}, \mathbf{c})$ and $0.2 \mu \mathrm{m}(\mathbf{d})$.

2.6. Cloning and Sequencing of PCR Products. DNA fragments obtained during PCR were cloned with CloneJet PCR Cloning Kit no. K1231 (Fermentas, EU). Transformation of competent XL-1 cells of Escherichia coli and plasmid purification were performed accordingly [13]. DNA sequencing was performed with ABI PRISM BigDye Terminator v. 3.1 at the Applied Biosystems 3730 DNA Analyzer (Center for Collective Use "Genome"). Sequences were edited and assembled with Bioedit (Invitrogen, Carlsbad, CA). Sequences were analyzed with BLAST software (http://www.ncbi.nlm.nih.gov/BLAST/) in order to identify their closest relatives. The full nucleotide sequences of the rRNA gene cluster of all three cyanobacteria were accomplished and deposited to GenBank under accession numbers HM064496.1, GU265558.1, and JQ259187.1.

2.7. Phylogenetic Analysis. Search of the nucleotide sequences in the database GenBank, homologous to the sequenced genes of studied species of cyanobacteria, was performed using BLAST (http://www.ncbi.nlm.nih.gov/entrez/viewer) with the option-the least degree of similarity (minimum identity). The sequences of selected species were aligned using the algorithm ClustalW v.1.6 (MEGA 5.1) [14]. Phylogenetic reconstructions were performed using clustering neighbor-joining method (MEGA 5.1) with the preselection of an adequate model of nucleotide substitutions. Statistical 


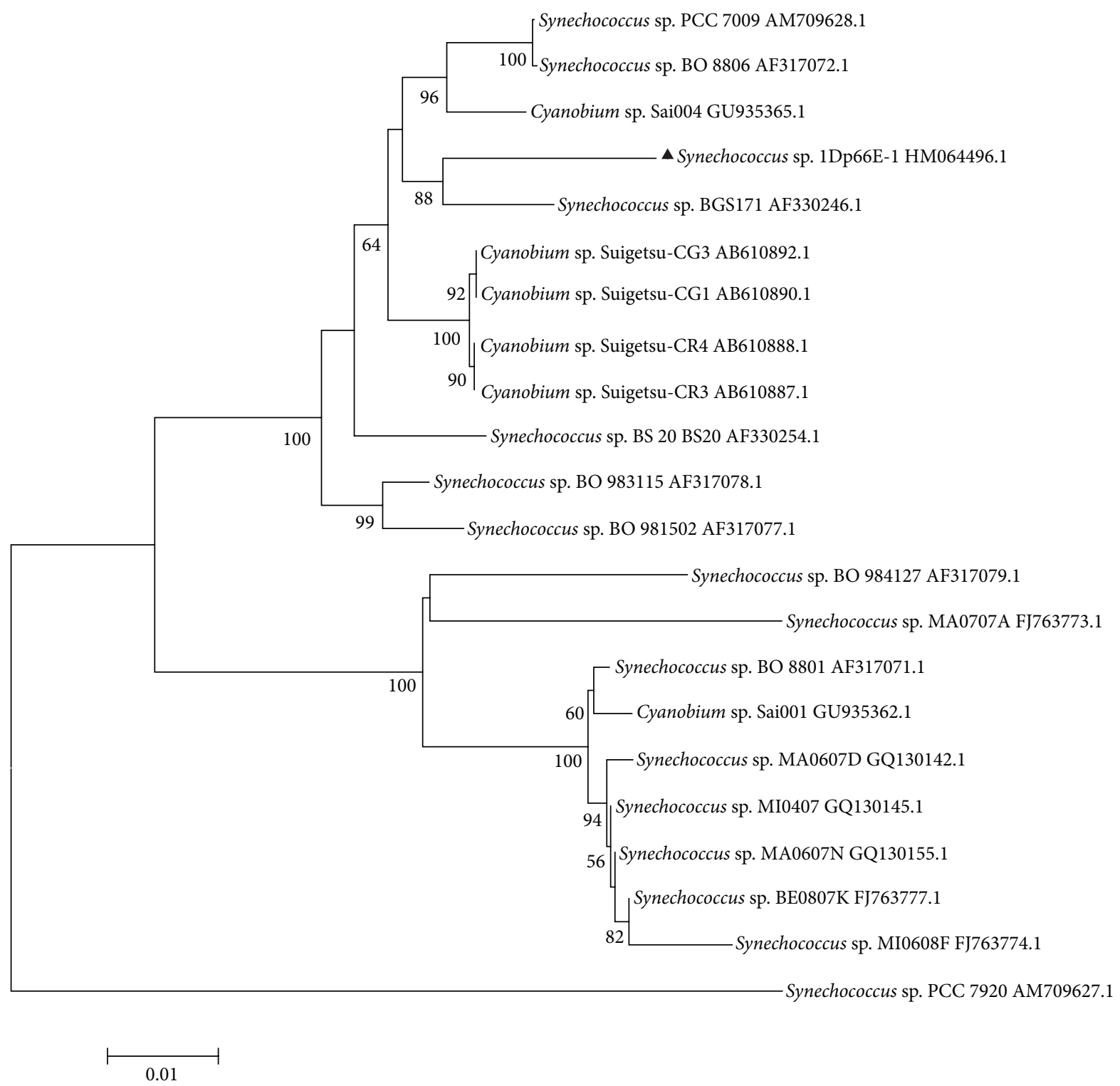

FIGURE 4: Phylogenetic relationships of Synechococcus sp. 1Dp66E-1 inferred under the neighbor-joining (NJ) criterion (MEGA 5.1 [14]) from gene for 16S rRNA, partial sequence; 16S-23S rRNA intergenic spacer, complete sequence; and 23S rRNA, partial sequence information. The numbers at the nodes indicate the level of bootstrap support based on neighbor-joining analysis of 1000 resampled datasets; only values higher than $50 \%$ are given. The scale bar indicates 0.01 substitutions per nucleotide position.

significance of the obtained dendrograms was calculated by bootstrap analysis by generation of 1000 permutations.

\section{Results and Discussion}

3.1. Morphological and Ultrastructural Characteristics and Identification of Cyanobacterial Isolates. Cyanobacterium 1Dp66E-1 was characterized by short rods (Table 2). These cells contained 2-3 thylakoids located in parallel to a cell surface. In the center of the cell there were a nucleoid, ribosomes, and carboxysomes (Figure 1). Visible polymers have been identified as granules of poly- $\beta$-hydroxybutyrate $(\mathrm{Phb})$ and polyphosphate. Cyanophycin granules were absent. As it was possible to see after negative staining, cells of $1 \mathrm{Dp} 66 \mathrm{E}-1$ were characterized by a rugulose relief of the cell surface. Similar surface type has been observed in cases of no phototrophic Gram-negative bacteria [15] and of cyanobacteria Synechococcus sp. PCC 6301 and Synechococcus sp. PCC 7942 [16]. On ultrathin sections the outer leaflet of the outer membrane of the cell wall looked like a structure of high electron density, and it was merged with an additional layer consisting of orderly packed subunits. This additional layer was similar to bacterial S-layer glycoprotein. The cyanobacterium 1Dp66E-1 had characteristics typical to genus of Synechococcus.

The study by light and electron microscopy revealed that cyanobacterium 2Dp86E was filamentous (Table 2; Figure 2). Trichomes were often bound into bundles and were surrounded by layered common sheathes, which had in local 


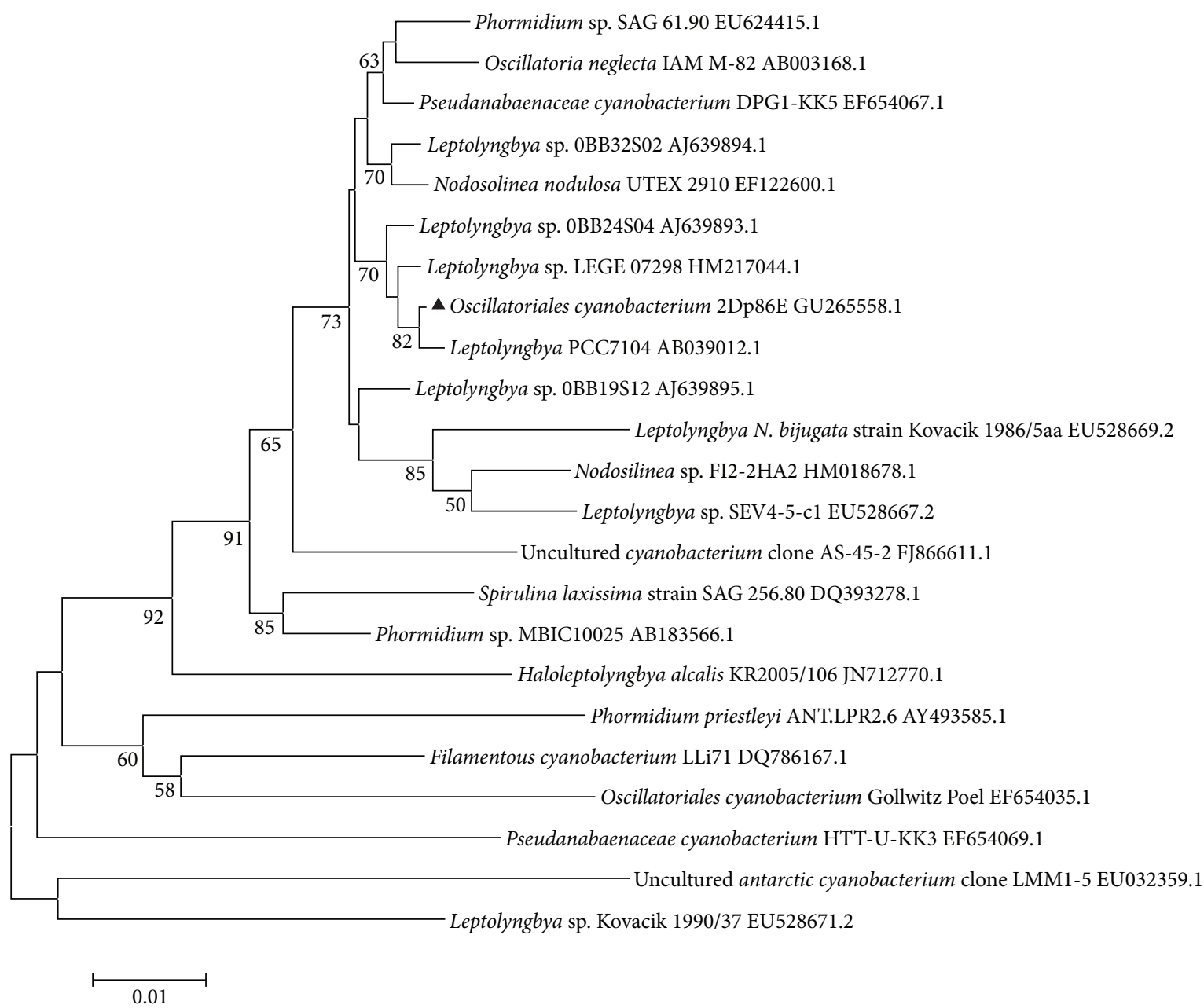

FIGURE 5: Phylogenetic relationships of Oscillatoriales cyanobacterium 2Dp86E inferred under the neighbor-joining (NJ) criterion (MEGA 5.1) from gene for $16 \mathrm{~S}$ rRNA, partial sequence; $16 \mathrm{~S}-23 \mathrm{~S}$ rRNA intergenic spacer, complete sequence; and $23 \mathrm{~S}$ rRNA, partial sequence information. The numbers at the nodes indicate the level of bootstrap support based on neighbor-joining analysis of 1000 resampled datasets; only values higher than $50 \%$ are given. The scale bar indicates 0.01 substitutions per nucleotide position.

TABLE 2: Morphological properties of cyanobacteria isolates.

\begin{tabular}{|c|c|c|}
\hline Isolate name & Morphology, type of cell division, and differentiation & $\begin{array}{l}\text { Subsection } \\
\text { (order) }^{*}\end{array}$ \\
\hline 1Dp66E-1 & $\begin{array}{l}\text { Unicellular, binary fission by constriction, cells sticks shaped } 0.6-0.8 \mu \mathrm{m} \\
\text { wide and } 1.5-2 \mu \mathrm{m} \text { long, unsheathed. }\end{array}$ & $\begin{array}{c}\mathrm{I} \\
\text { (Chroococcales) }\end{array}$ \\
\hline 2Dp86E & $\begin{array}{l}\text { Filamentous, binary fission in one plane by septum formation, no cell } \\
\text { differentiation, ensheathed, cells barrel or cylindrical shaped } 1.5-2.5 \mu \mathrm{m} \\
\text { long and } 1.0-1.5 \mu \mathrm{m} \text { wide. }\end{array}$ & $\begin{array}{c}\text { III } \\
\text { (Oscillatoriales) }\end{array}$ \\
\hline 10Dp66E & $\begin{array}{l}\text { Filamentous, binary fission in one plane by septum formation, cells round } \\
\text { shaped } 3.0-3.5 \mu \mathrm{m} \text { in diameter and are able to differentiate hormogonia } \\
\text { and intercalary heterocysts and akinetes. Vegetative trichomes have their } \\
\text { own sheaths and are joined by colonial mucus. }\end{array}$ & $\begin{array}{c}\text { IV } \\
\text { (Nostocales) }\end{array}$ \\
\hline
\end{tabular}

${ }^{*}$ Classification was performed according to Castenholz [25].

areas sleeve-like bulges (Figure 2). In the structure of many sheaths, there were revealed electron transparent sections. The sheaths of neighboring trichomes could be closely contacted. The end cells in trichomes usually are smaller and narrower at the terminal parts. Cells of this isolate had
4-6 thylakoids, located on the periphery of the cytoplasm and in parallel to a cell surface. Nucleoid, carboxysomes, polyphosphate, and Phb-like granules were located in the cell center (Figure 2). Clusters of ribosomes were concentrated around the nucleoid. Cyanophycin granules were rare. 


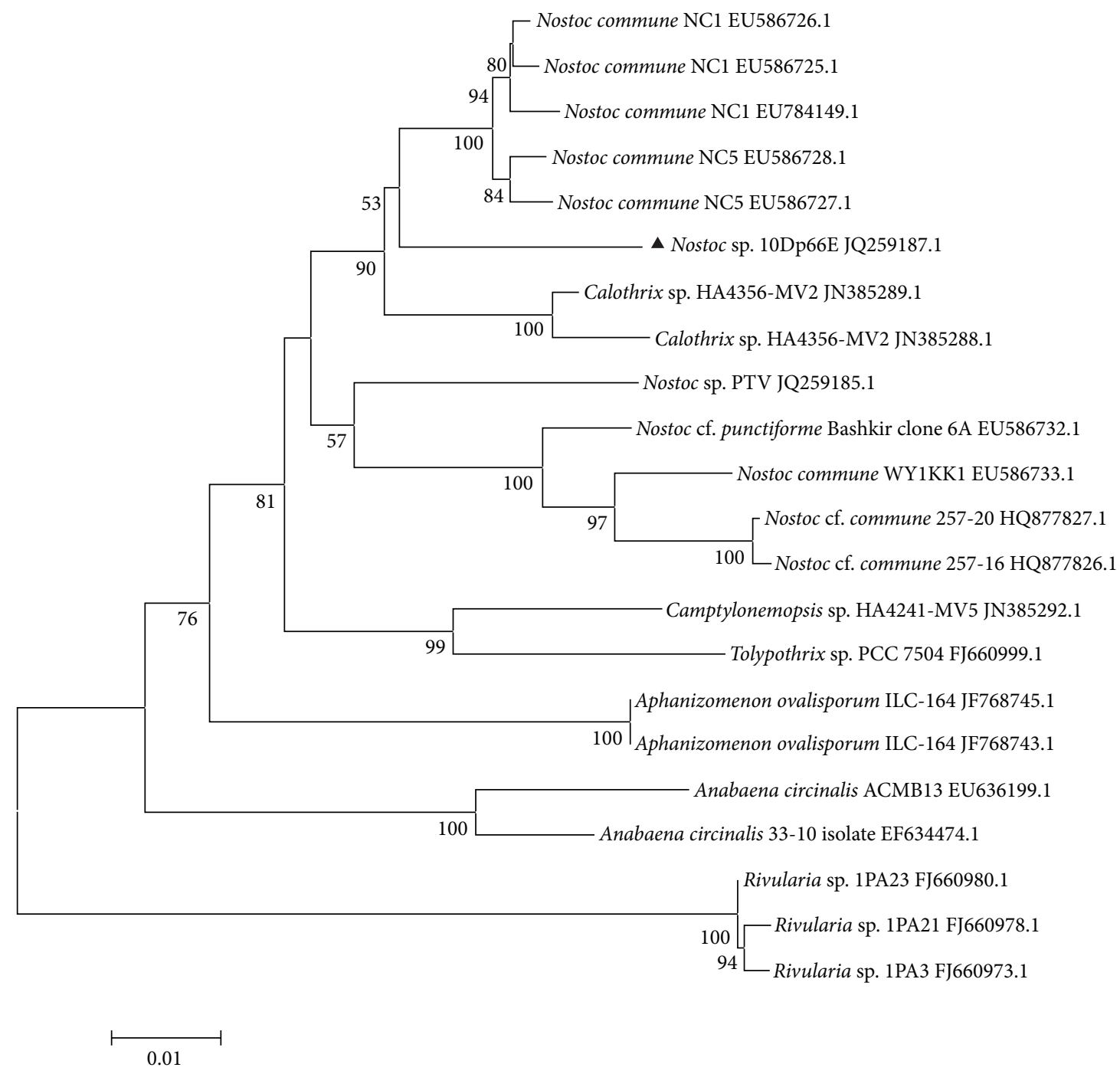

FIGURE 6: Phylogenetic relationships of Nostoc sp. 10Dp66E inferred under the neighbor-joining (NJ) criterion (MEGA 5.1) from gene for 16S rRNA, partial sequence; 16S-23S rRNA intergenic spacer, complete sequence; and 23S rRNA, partial sequence information. The numbers at the nodes indicate the level of bootstrap support based on neighbor-joining analysis of 1000 resampled datasets; only values higher than $50 \%$ are given. The scale bar indicates 0.01 substitutions per nucleotide position.

Despite the fact that this strain was able to greatly accumulate phycocyanin [7], phycobilisomes on ultrathin sections were not detected due to the high density of the surrounding cytoplasm. From the combination of morphological and ultrastructural signs of cyanobacteria 2Dp86E had similarities with the representatives of the genus Leptolyngbya, which includes groups of filamentous cyanobacteria in LPP-group B that exhibit very thin trichomes $(<3 \mu \mathrm{m})[17,18]$.

Isolate 10Dp66E was a filamentous cyanobacterium (Figure 3, Table 2). Depending on the phase of the culture development in the colonies of cyanobacteria dominated hormogonia, long-row vegetative trichomes with intercalary heterocysts and akinetes, or rounded clusters formed by twisted trichomes. Many chains of cells were "dressed" by one- or multilayer fibrillar sheaths (Figure 3). Colonial mucus and extracellular matrix of clusters were composed from loosely packed reticular-fibrous and granular materials. Peripheral layer of mucous extracellular matrix was compacted and was common for the entire cluster. Bacteria of different morphotypes were localized in colonial mucus, in the intercellular matrix, and in sheaths of trichomes. A feature of this cyanobacterium is the differentiation of heterocysts even in presence of combined nitrogen in the medium. Photosynthetic apparatus of cyanobacterium 10Dp66E was represented by randomly distributed thylakoids in the cytoplasm. Intrathylakoid space could be increased and in some cases was filled by mesh substance. Nucleoid, ribosomes, and carboxysomes are located between thylakoids. In the 10Dp66E, cells were accumulated with glycogen, Phb, cyanophycin, protein granules, and lipid globules 
TABLE 3: BLAST results obtained by querying the 16S-23S rRNA gene cluster of Synechococcus sp. 1Dp66E-1 with GenBank and geographical and ecological origins of the hits.

\begin{tabular}{|c|c|c|c|c|c|c|}
\hline $\begin{array}{l}\text { Closest GenBank } \\
\text { relative }\end{array}$ & GenBank number & $\begin{array}{c}\text { Query } \\
\text { coverage \% }\end{array}$ & Score $\%$ & Identity \% & $E$-value & Origin of the strain and reference \\
\hline $\begin{array}{l}\text { Cyanobium sp. } \\
\text { Suigetsu-CG3 }\end{array}$ & AB610892.1 & 99 & 3469 & 95 & 0 & $\begin{array}{l}\text { Picocyanobacteria isolated from } \\
\text { the surface layer permanent } \\
\text { halocline of the saline (from } \\
0.4 \% \text { to } 1.4 \% \text { ) meromictic Lake } \\
\text { Suigetsu, }\left(35^{\circ} 35^{\prime} \mathrm{N}, 135^{\circ} 52^{\prime} \mathrm{E},\right. \\
\text { coast of the Japan Sea in Fukui } \\
\text { Prefecture, Japan) [26]. }\end{array}$ \\
\hline $\begin{array}{l}\text { Synechococcus sp. } \\
\text { PCC } 7009\end{array}$ & AM709628.1 & 99 & 3431 & 94 & 0 & $\begin{array}{l}\text { Originated from CA, USA. It was } \\
\text { placed then in PCC collection. }\end{array}$ \\
\hline $\begin{array}{l}\text { Synechococcus sp. } \\
\text { BGS171 }\end{array}$ & AF330246.1 & 98 & 3422 & 93 & 0 & $\begin{array}{l}\text { Picocyanobacteria isolated from } \\
\text { the fresh water Lake Constance } \\
\left(47^{\circ} 39^{\prime} \mathrm{N} 9^{\circ} 19^{\prime} \mathrm{E}\right) \text { Europe [27]. }\end{array}$ \\
\hline $\begin{array}{l}\text { Synechococcus sp. } \\
\text { BO8806 }\end{array}$ & AF317072.1 & 98 & 3388 & 94 & 0 & $\begin{array}{l}\text { Picocyanobacteria isolated from } \\
\text { the fresh water Lake Balaton } \\
\left(46^{\circ} 50^{\prime} \mathrm{N} 17^{\circ} 44^{\prime} \mathrm{E}\right) \text { Europe [27]. }\end{array}$ \\
\hline $\begin{array}{l}\text { Synechococcus sp. } \\
\text { BO983115 }\end{array}$ & AF317078.1 & 98 & 3377 & 94 & 0 & $\begin{array}{l}\text { Picocyanobacteria isolated from } \\
\text { the fresh water Lake Balaton } \\
\left(46^{\circ} 50^{\prime} \mathrm{N} 17^{\circ} 44^{\prime} \mathrm{E}\right) \text { Europe [27]. }\end{array}$ \\
\hline $\begin{array}{l}\text { Synechococcus sp. } \\
\text { BO981502 }\end{array}$ & AF317077.1 & 98 & 3341 & 94 & 0 & $\begin{array}{l}\text { Picocyanobacteria isolated from } \\
\text { the fresh water Lake Balaton } \\
\left(46^{\circ} 50^{\prime} \mathrm{N} 17^{\circ} 44^{\prime} \mathrm{E}\right) \text { Europe [27]. }\end{array}$ \\
\hline $\begin{array}{l}\text { Synechococcus sp. } \\
\text { BS20 }\end{array}$ & AF330254.1 & 98 & 3321 & 94 & 0 & $\begin{array}{l}\text { Picocyanobacteria isolated from } \\
\text { the Bornholm Sea }\left(55^{\circ} 07^{\prime} \mathrm{N}\right. \\
\left.14^{\circ} 55^{\prime} \mathrm{E}\left(\text { salinity } 9 \mathrm{~g} \mathrm{~L}^{-1}\right)\right) \text {, Baltic } \\
\text { Sea, Europe [27]. }\end{array}$ \\
\hline $\begin{array}{l}\text { Cyanobium sp. } \\
\text { Sai004 }\end{array}$ & GU935365.1 & 97 & 3296 & 94 & 0 & $\begin{array}{l}\text { Cyanobacteria isolated from the } \\
\text { drinking water of the dam in the } \\
\text { Saidenbach Saxony (Germany), } \\
\text { Europe [Schumann, } \\
\text { unpublished]. }\end{array}$ \\
\hline
\end{tabular}

(Figure 3). By morphological criteria and ultrastructural features, cyanobacterium 10Dp66E was similar to representatives of the genus Nostoc.

3.2. Phylogenetic Analysis of the Ribosomal RNA Operons. To identify and to determine the phylogenetic positions of the new cyanobacterial isolates purified from native samples of the sublittoral hydroid D. pumila, we used 16 S ribosomal RNA gene cluster as a molecular marker. Cloning and sequencing of the DNA fragment, containing 16S ribosomal RNA gene and 16S-23S ribosomal RNA intergenic spacer sequences, have been performed for all three isolated strains using appropriate primers (Table 1). Comparison of rRNA gene cluster sequence $(2277 \mathrm{bp}$ ) of the cyanobacterium 1Dp66E1 revealed that $1 \mathrm{Dp} 66 \mathrm{E}-1$ shows the highest similarity with several strains of Synechococcus (Table 3). Phylogenetic analysis (Figure 4) revealed that the cyanobacterium 1Dp66E-1 forms the unique evolutionary branch and belongs to a cluster of picocyanobacteria Synechococcus, which includes freshand seawater strains. One group of closely related organisms had been isolated from freshwater European lakes (Table 3). The closest relatives of the 1Dp66E-1 are Synechococcus sp. BO981502, isolated from Lake Balaton, and Synechococcus sp. BGS171, isolated from Lake Constance (Bodensee). Another strain of the genus Synechococcus (Synechococcus sp. BS20) was isolated from the Baltic Sea near the Danish island of Bornholm. The strain Synechococcus sp. PCC 7009 was originated from the USA, whereas the Cyanobium sp. Suigetsu-CG3 was purified from a lake in Japan (Table 3). Thus, the majority of Synechococcus strains that are closely related to 1Dp66E-1 have been isolated from marine and freshwater habitats of Europe, as well of the USA and Japan. These organisms exist in the form of plankton. However, the strain of Synechococcus sp. PCC 7009 was clustered with chromatophore (photosynthetic endosymbiont) of the freshwater filose amoeba Paulinella chromatophora. This endosymbiont has cyanobacterial origin, and it is closely related to freeliving Prochlorococcus and Synechococcus species [19]. Here, we demonstrate that the picocyanobacterium Synechococcus sp. $1 \mathrm{Dp} 66 \mathrm{E}-1$ is associated with the invertebrate of White Sea.

DNA fragment of $1732 \mathrm{bp}$ (GU265558.1) containing almost complete sequence of the genes coding for $16 \mathrm{~S}$ rRNA, internal transcribed spacer 16S-23S rRNA, and part of the gene for $23 \mathrm{~S}$ rRNA of the cyanobacterium 2Dp86E (GeneBank accession no. GU265558.1) has the highest similarity with analogous sequences of different Leptolyngbya 
TABLE 4: BLAST results obtained by querying the 16S-23S rRNA gene cluster of Oscillatoriales cyanobacterium 2Dp86E with GenBank, and geographical and ecological origins of the hits.

\begin{tabular}{|c|c|c|c|c|c|c|}
\hline $\begin{array}{l}\text { Closest GenBank } \\
\text { relative }\end{array}$ & GenBank number & Query coverage \% & Score \% & Identity \% & $E$-value & $\begin{array}{l}\text { Origin of the strain and } \\
\text { reference }\end{array}$ \\
\hline $\begin{array}{l}\text { Leptolyngbya } \\
\text { PCC7104 }\end{array}$ & АВ039012.1 & 66 & 2035 & 99 & 0 & $\begin{array}{l}\text { Long Island, NY, USA, } \\
\text { Montauk Point [28]. }\end{array}$ \\
\hline $\begin{array}{l}\text { Leptolyngbya sp. } \\
\text { LEGE } 07298\end{array}$ & HM217044.1 & 65 & 2013 & 99 & 0 & $\begin{array}{l}\text { Cyanobacteria from three } \\
\text { Portuguese temperates }\end{array}$ \\
\hline $\begin{array}{l}\text { Leptolyngbya sp. } \\
\text { 0BB24S04 }\end{array}$ & AJ639893.1 & 67 & 2082 & 99 & 0 & $\begin{array}{l}\text { Bubano Basin, Imola, Italy } \\
{[30] \text {. }}\end{array}$ \\
\hline $\begin{array}{l}\text { Leptolyngbya sp. } \\
\text { 0BB19S12 }\end{array}$ & AJ639895.1 & 67 & 2046 & 99 & 0 & $\begin{array}{l}\text { Bubano Basin, Imola, Italy } \\
{[30] \text {. }}\end{array}$ \\
\hline $\begin{array}{l}\text { Leptolyngbya sp. } \\
\text { 0BB32S02 }\end{array}$ & AJ639894.1 & 67 & 2033 & 99 & 0 & $\begin{array}{l}\text { Bubano Basin, Imola, Italy } \\
{[30] .}\end{array}$ \\
\hline $\begin{array}{l}\text { Nodosilinea sp. } \\
\text { FI2-2HA2 }\end{array}$ & НМ018678.1 & 96 & 2596 & 95 & 0 & $\begin{array}{l}\text { Fort Irwin, California, } \\
\text { Mojave Desert, soil [31]. }\end{array}$ \\
\hline $\begin{array}{l}\text { Leptolyngbya sp. } \\
\text { Kovacik 1986/5 aa }\end{array}$ & EU528669.2 & 99 & 2475 & 92 & 0 & $\begin{array}{l}\text { Poland: Lake Piaseczno } \\
\text { littoral region } \\
\text { [Casamatta, unpublished]. }\end{array}$ \\
\hline $\begin{array}{l}\text { Leptolyngbya sp. } \\
\text { SEV4-5-c1 }\end{array}$ & EU528667.2 & 76 & 2152 & 97 & 0 & $\begin{array}{l}\text { Desert soil } \\
\text { [Casamatta, unpublished]. }\end{array}$ \\
\hline $\begin{array}{l}\text { Nodosolinea } \\
\text { nodulosa UTEX } 2910\end{array}$ & $\mathrm{EF} 122600.1$ & 64 & 1954 & 99 & 0 & $\begin{array}{l}\text { South China Sea (marine), } \\
\text { plankton tow, } 10 \mathrm{~m} \text { depth } \\
{[32] .}\end{array}$ \\
\hline
\end{tabular}

TABLE 5: BLAST results obtained by querying the 16S-23S rRNA gene cluster of Nostoc sp. 10Dp66E with GenBank and geographical and ecological origins of the hits.

\begin{tabular}{|c|c|c|c|c|c|c|c|}
\hline $\begin{array}{l}\text { Closest } \\
\text { GenBank } \\
\text { relative }\end{array}$ & $\begin{array}{l}\text { GenBank } \\
\text { number }\end{array}$ & $\begin{array}{c}\text { Query } \\
\text { coverage \% }\end{array}$ & Score $\%$ & Identity \% & $E$-value & Origin of the strain & Reference \\
\hline $\begin{array}{l}\text { Nostoc } \\
\text { commune } \\
\text { NC1 clone } 10\end{array}$ & EU586726.1 & 92 & 2693 & 94 & 0 & Unknown & $\begin{array}{l}\text { N. commune Vaucher } \\
\text { exBornet et Flahault } \\
\text { [Johansen J. R. et al., } \\
\text { unpublished]. }\end{array}$ \\
\hline $\begin{array}{l}\text { Nostoc } \\
\text { commune } \\
\text { NC5 clone } 11\end{array}$ & EU586728.1 & 92 & 2666 & 94 & 0 & Unknown & $\begin{array}{l}\text { N. commune Vaucher } \\
\text { exBornet et Flahault } \\
\text { [Johansen J. R. et al., } \\
\text { unpublished]. }\end{array}$ \\
\hline $\begin{array}{l}\text { Nostoc } \\
\text { commune } \\
\text { NC1 }\end{array}$ & EU784149.1 & 92 & 2681 & 94 & 0 & Unknown & $\begin{array}{l}\text { Isolated from meadow } \\
\text { soil, close Vrbensky } \\
\text { pond, Ceske Budejovice, } \\
\text { Czech Republic } \\
\text { [Rehakova K., } \\
\text { unpublished]. }\end{array}$ \\
\hline $\begin{array}{l}\text { Calothrix sp. } \\
\text { HA4356-MV2 }\end{array}$ & JN385289.1 & 99 & 2634 & 92 & 0 & $\begin{array}{l}\text { Cave wall scraping, Maniniholo } \\
\text { cave near Haena, Hawaii }\end{array}$ & {$[33]$} \\
\hline $\begin{array}{l}\text { Calothrix sp. } \\
\text { HA4356-MV2 }\end{array}$ & JN385288.1 & 81 & 2634 & 96 & 0 & $\begin{array}{l}\text { Isolated from the island of Oahu } \\
\left(21^{\circ} 28^{\prime} \mathrm{N} 157^{\circ} 59^{\prime} \mathrm{W}\right) \text {, Hawaii }\end{array}$ & {$[33]$} \\
\hline
\end{tabular}

strains (Table 4), and it is clustered with the representatives of the genus Leptolyngbya (Figure 5). The latter have been isolated from freshwater lakes in Italy and Poland (European lakes), estuaries of benthic temperate of Portugal, and from the desert soils of North America (Table 4). All these closely related organisms of the $2 \mathrm{Dp} 86 \mathrm{E}$ have been isolated from freshwater and soil habitats. There is only one representative of the marine species which is related to the $2 \mathrm{Dp} 86 \mathrm{E}$. Until now, eight species of Leptolyngbya have been found in White Sea: they have been isolated from fouling stones, or, as Leptolyngbya mucicola - the endofit from colonies of Rivularia coadunata [20]. In addition, several Leptolyngbya 
strains have been identified in White Sea, which inhabit areas of varying salinity [21]. However, all mentioned strains have not been analyzed with molecular methods.

Analysis of the nucleotide sequence (1902 bp) of the $16 \mathrm{~S}$ rRNA gene cluster of the Nostoc sp. 10Dp66E (JQ259187.1) revealed that it has no identity to any of previously studied organisms. Cyanobacterium 10Dp66E has similarity with several strains of Nostoc commune (Table 5). It forms the unique branch and belongs to a cluster of Nostoc, with the closest relative of Nostoc commune isolates (Figure 6). There are only two strains of Nostoc, namely, Nostoc commune Vaucher ex Bornet et Flahault and Nostoc zetterstedtii Aresch. ex Bornet et Flahault, that had been detected in White Sea so far [20]. No information is available on the molecular typing of these strains. However, it is possible that Nostoc commune Vaucher ex Bornet et Flahault might represent the same strain as Nostoc commune NC1 clone 10 and Nostoc commune NC5 clone 11, that were defined in the GenBank (Table 5). Nostoc commune $\mathrm{NCl}$ (EU784149.1) was isolated from meadow soils, close to Vrbensky ponds, Ceske Budejovice, Czech Republic.

Cyanobacterial mucous sheaths provide the specific econiches-environments for numerous heterotrophic bacteria. In this work, using $16 \mathrm{~S}$ rRNA gene, we first identified the heterotrophic bacterium associated with Nostoc sp. 10Dp66E. This bacterium is a member of the genus Gemmatimonas (JX437625.1). The Gemmatimonadetes represents recently described bacterial group whose members are widespread in nature. These bacteria which are phylogenetically novel Gram-negative aerobic heterotrophs are capable of accumulating polyphosphates [22]. Gemmatimonas was found in associations with sponge [6].

\section{Conclusions}

Based on phenotypic and genotypic characteristics, we identified new cyanobacteria from association with the hydroid Dynamena pumila living in White Sea. Two of them form the unique branches in the corresponding phylogenetic trees. Among species clustered with the new cyanobacterial isolates there are fresh- and seawater strains from Europe, America, and Japan. The identified strains are mostly photoautotrophic, but some of them are diazotrophic bacteria. Future biochemical and genetic experiments will help to understand metabolic relations between these bacterial isolates and the hydroid Dynamena pumila in the association.

\section{Acknowledgment}

This work was supported by Grants nos. 09-04-00675 and 1104-00774 of the Russian Foundation for Basic Research.

\section{References}

[1] E. J. Carpenter and R. A. Foster, "Marine cyanobacterial symbiosis," in Cyanobacteria Symbiosis, A. N. Rai, B. Bergman, and U. Rasmussen, Eds., pp. 11-17, Academic Kluwer, Dordrecht, The Netherlands, 2002.

[2] M. P. Lesser, C. H. Mazel, M. Y. Gorbunov, and P. G. Falkowski, "Discovery of symbiotic nitrogen-fixing cyanobacteria in corals," Science, vol. 305, no. 5686, pp. 997-1000, 2004.
[3] R. A. Foster, E. J. Carpenter, and B. Bergman, "Unicellular cyanobionts in open ocean dinoflagellates, radiolarians, and tintinnids: ultrastructural characterization and immuno-localization of phycoerythrin and nitrogenase," Journal of Phycology, vol. 42, no. 2, pp. 453-463, 2006.

[4] T. Romagnoli, G. Bavestrello, E. M. Cucchiari et al., "Microalgal communities epibiontic on the marine hydroid Eudendrium racemosum in the Ligurian Sea during an annual cycle," Marine Biology, vol. 151, no. 2, pp. 537-552, 2007.

[5] A. A. Venn, J. E. Loram, and A. E. Douglas, "Photosynthetic symbioses in animals," Journal of Experimental Botany, vol. 59, no. 5, pp. 1069-1080, 2008.

[6] M. W. Taylor, R. Radax, D. Steger, and M. Wagner, "Spongeassociated microorganisms: evolution, ecology, and biotechnological potential," Microbiology and Molecular Biology Reviews, vol. 71, no. 2, pp. 295-347, 2007.

[7] O. Gorelova, I. Kosevich, O. Baulina, T. Fedorenko, A. Torshkhoeva, and E. S. Lobakova, "Associations between the white sea invertebrates and oxygen-evolving phototrophic microorganisms," Moscow University Biological Sciences Bulletin, vol. 64, no. 1, pp. 16-22, 2009.

[8] O. A. Gorelova, O. I. Baulina, I. A. Kosevich, and E. S. Lobakova, "Associations between the White Sea colonial hydroid Dynamena pumila and microorganisms," Journal of the Marine Biological Association of the UK, vol. 93, no. 1, pp. 69-80, 2013.

[9] R. Y. Stanier, R. Kunisawa, M. Mandel, and G. Cohen-Bazire, "Purification and properties of unicellular blue-green algae (order Chroococcales)," Bacteriological Reviews, vol. 35, no. 2, pp. 171-205, 1971.

[10] E. S. Reynolds, "The use of lead citrate at high $\mathrm{pH}$ as an electron-opaque stain in electron microscopy," The Journal of Cell Biology, vol. 17, pp. 208-212, 1963.

[11] O. Koksharova, M. Schubert, S. Shestakov, and R. Cerff, "Genetic and biochemical evidence for distinct key functions of two highly divergent GAPDH genes in catabolic and anabolic carbon flow of the cyanobacterium Synechocystis sp. PCC 6803," Plant Molecular Biology, vol. 36, no. 1, pp. 183-194, 1998.

[12] D. Papaefthimiou, P. Hrouzek, M. A. Mugnai et al., "Differential patterns of evolution and distribution of the symbiotic behaviour in nostocacean cyanobacteria," International Journal of Systematic and Evolutionary Microbiology, vol. 58, no. 3, pp. 553-564, 2008.

[13] J. Sambrook, E. F. Fritsch, and T. Maniatis, Molecular Cloning: A Laboratory Manual, Cold Spring Harbor Laboratory Press, New York, NY, USA, 2nd edition, 1989.

[14] K. Tamura, D. Peterson, N. Peterson, G. Stecher, M. Nei, and S. Kumar, "MEGA5: molecular evolutionary genetics analysis using maximum likelihood, evolutionary distance, and maximum parsimony methods," Molecular Biology and Evolution, vol. 28, no. 10, pp. 2731-2739, 2011.

[15] L. O. Zwillenberg, "Electron microscopic features of gramnegative and gram-positive bacteria embedded in phosphotungstate," Antonie van Leeuwenhoek, vol. 30, no. 1, pp. 154-162, 1964.

[16] O. A. Gorelova, O. I. Baulina, U. Rasmussen, and O. A. Koksharova, "The pleiotropic effects of $f t n 2$ and $f t n 6$ mutations in cyanobacterium Synechococcus sp. PCC 7942: an ultrastructural study," Protoplasma, 2013.

[17] R. Rippka, J. Deruelles, and J. B. Waterbury, "Generic assignments, strain histories and properties of pure cultures of cyanobacteria," Journal of General Microbiology, vol. 111, no. 1, pp. 1-61, 1979. 
[18] L. Bruno, D. Billi, S. Bellezza, and P. Albertano, "Cytomorphological and genetic characterization of troglobitic Leptolyngbya strains isolated from Roman hypogea," Applied and Environmental Microbiology, vol. 75, no. 3, pp. 608-617, 2009.

[19] B. Marin, E. C. M. Nowack, G. Glöckner, and M. Melkonian, "The ancestor of the Paulinella chromatophore obtained a carboxysomal operon by horizontal gene transfer from a Nitrococcus-like $\gamma$-proteobacterium," BMC Evolutionary Biology, vol. 7, article 85, 2007.

[20] R. N. Beliakova, "Cyanophyta reservati kandalakshnsis," in Novitates Systematicae Plantarum Non Vascularium, K. L. Vinogradov, Ed., vol. 31, pp. 9-16, Nauka, St. Peterburg, Russia, 1996.

[21] A. Ulanova, Algae of ponds with unstable salinity coasts of the White and Barents Seas [Ph.D. thesis], St. Peterburg, Russia, 2003.

[22] H. Zhang, Y. Sekiguchi, S. Hanada et al., "Gemmatimonas aurantiaca gen. nov., sp. nov., a Gram-negative, aerobic, polyphosphate-accumulating micro-organism, the first cultured representative of the new bacterial phylum Gemmatimonadetes phyl. nov," International Journal of Systematic and Evolutionary Microbiology, vol. 53, no. 4, pp. 1155-1163, 2003.

[23] U. Nübel, F. Garcia-Pichel, and G. Muyzer, "PCR primers to amplify 16S rRNA genes from cyanobacteria," Applied and Environmental Microbiology, vol. 63, no. 8, pp. 3327-3332, 1997.

[24] A. Taton, S. Grubisic, E. Brambilla, R. De Wit, and A. Wilmotte, "Cyanobacterial diversity in natural and artificial microbial mats of Lake Fryxell (McMurdo Dry Valleys, Antarctica): a morphological and molecular approach," Applied and Environmental Microbiology, vol. 69, no. 9, pp. 5157-5169, 2003.

[25] R. W. Castenholz, "Phylum BX. Cyanobacteria. Oxygenic photosynthetic bacteria," in Bergey's Manual of Systematic Bacteriol$o g y$, D. R. Boone and R. W. Castenholz, Eds., vol. 1, pp. 473-599, 2nd edition, 2001.

[26] K. Ohki, K. Yamada, M. Kamiya, and S. Yoshikawa, "Characterization of picocyanobacteria isolated from the halocline of the saline meromictic lake, Lake Suigetsu, Japan," in Proceedings of the 13th International Symposium on Phototrophic Prokaryotes Montréal, p. 50, August 2009.

[27] A. Ernst, S. Becker, U. I. A. Wollenzien, and C. Postius, "Ecosystem-dependent adaptive radiations of picocyanobacteria inferred from 16S rRNA and ITS-1 sequence analysis," Microbiology, vol. 149, no. 1, pp. 217-228, 2003.

[28] T. Ishida, M. M. Watanabe, J. Sugiyama, and A. Yokota, "Evidence for polyphyletic origin of the members of the orders of Oscillatoriales and Pleurocapsales as determined by $16 \mathrm{~S}$ rDNA analysis," FEMS Microbiology Letters, vol. 201, no. 1, pp. 79-82, 2001.

[29] V. R. Lopes, V. Ramos, A. Martins et al., "Phylogenetic, chemical and morphological diversity of cyanobacteria from Portuguese temperate estuaries," Journal of Marine Environmental, vol. 73, pp. 7-16, 2012.

[30] B. Castiglioni, E. Rizzi, A. Frosini et al., "Development of a universal microarray based on the ligation detection reaction and 16S rRNA gene polymorphism to target diversity of cyanobacteria," Applied and Environmental Microbiology, vol. 70, no. 12, pp. 7161-7172, 2004.

[31] R. B. Perkerson, J. R. Johansen, L. Kovacik, J. Brand, J. Kastovsky, and D. A. Casamatta, "A unique Pseudanabaenalean (Cyanobacteria) genus Nodosilinea gen. nov. based on morphological and molecular data," Journal of Phycology, vol. 47, no. 6, pp. 1397-1412, 2011.
[32] Z. Li and J. Brand, "Leptolyngbya Nodulosa sp. nov. (Oscillatoriaceae), a subtropical marine cyanobacterium that produces a unique multicellular structure," Phycologia, vol. 46, no. 4, pp. 396-401, 2007.

[33] M. A. Vaccarino and J. R. Johansen, "Scytonematopsis contorta sp. nov. (Nostocales), a new species from the Hawaiian Islands," Fottea, vol. 11, no. 1, pp. 149-161, 2011. 

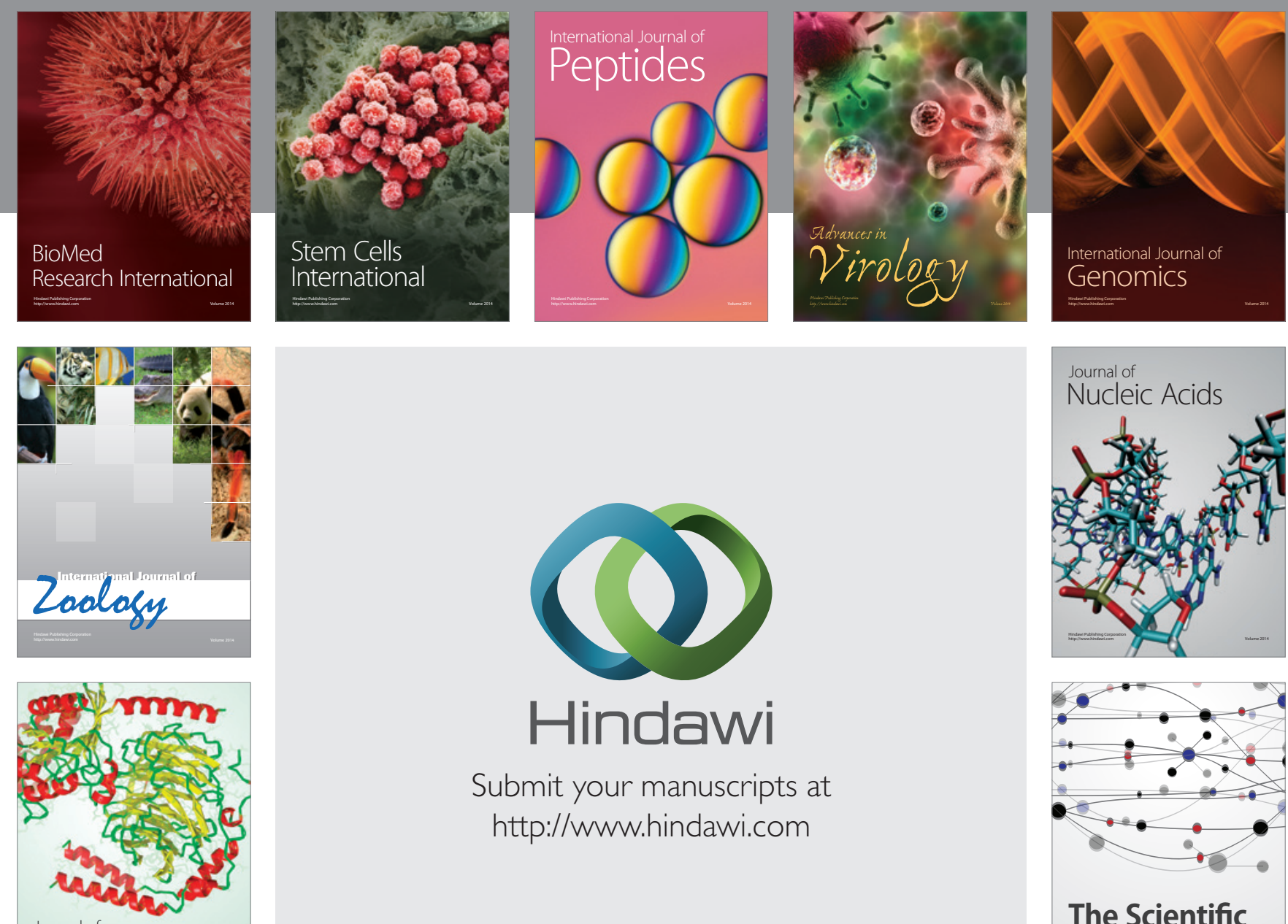

Submit your manuscripts at

http://www.hindawi.com

Journal of
Signal Transduction
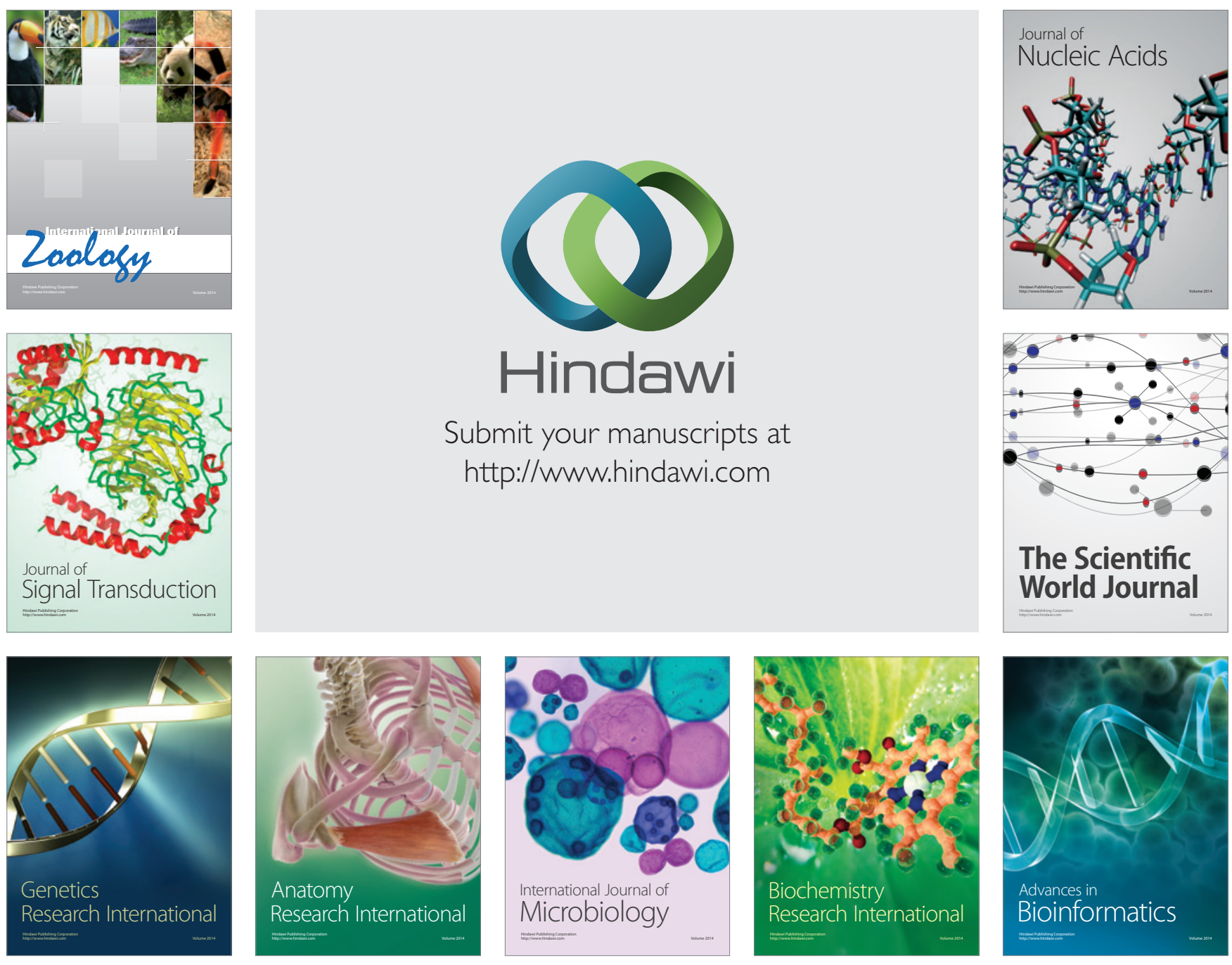

The Scientific World Journal
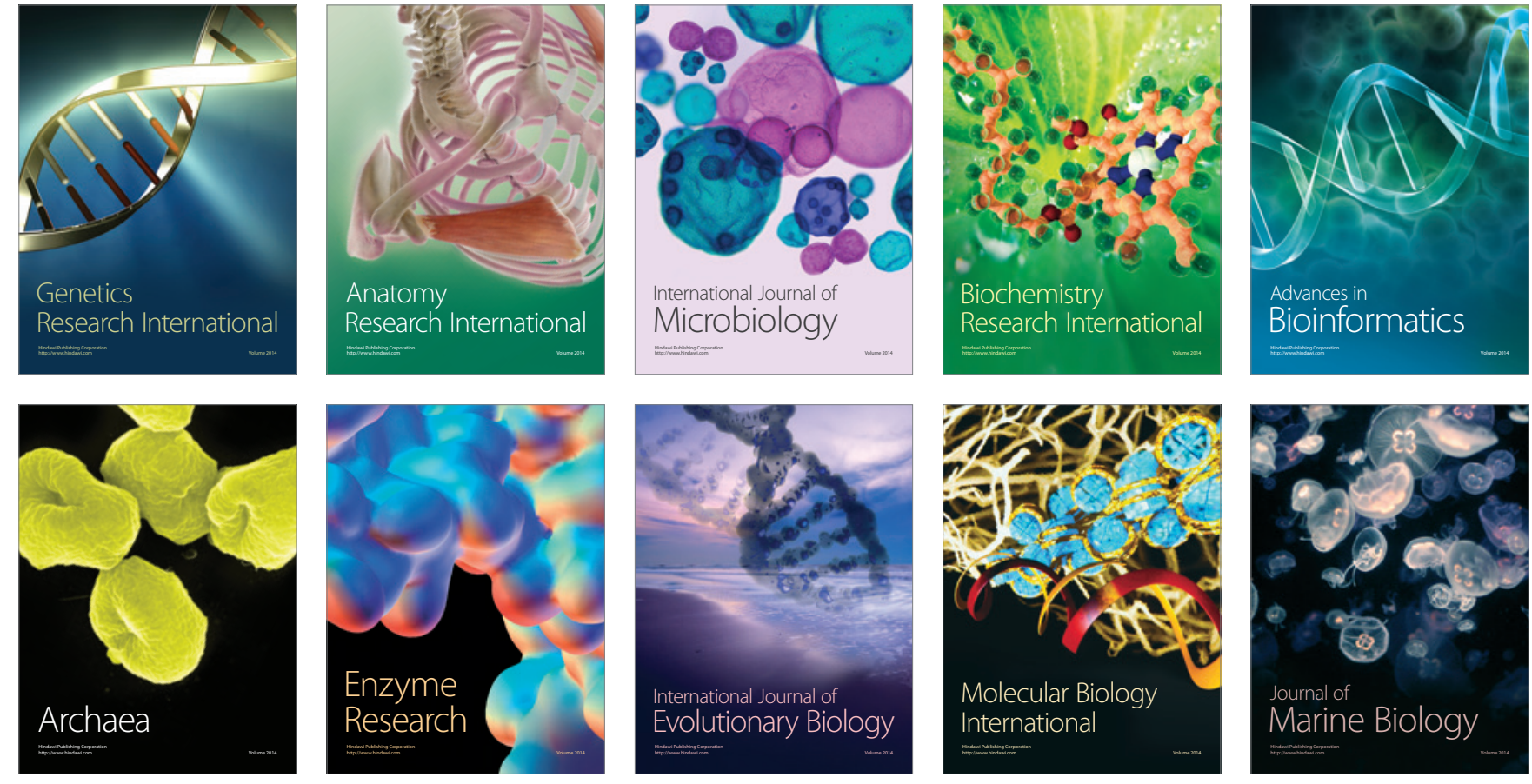